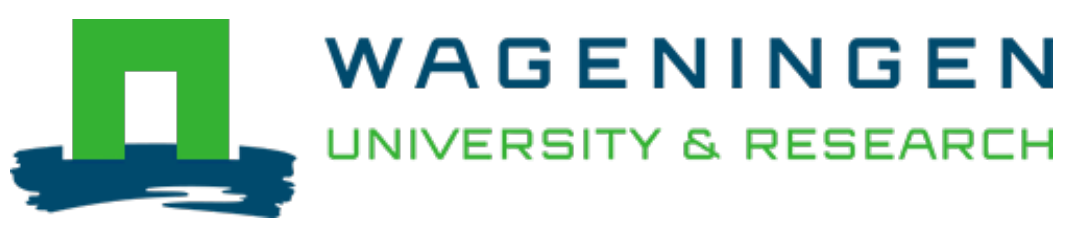

\title{
Spoilage evaluation, shelf-life prediction, and potential spoilage organisms of tropical brackish water shrimp (Penaeus notialis) at different storage temperatures
}

\author{
Food Microbiology
}

Dabade, D.S.; Besten, H.M.W.; Azokpota, P.; Nout, M.J.R.; Hounhouigan, D.J. et al

https://doi.org/10.1016/j.fm.2014.11.005

This publication is made publicly available in the institutional repository of Wageningen University and Research, under the terms of article $25 \mathrm{fa}$ of the Dutch Copyright Act, also known as the Amendment Taverne. This has been done with explicit consent by the author.

Article 25 fa states that the author of a short scientific work funded either wholly or partially by Dutch public funds is entitled to make that work publicly available for no consideration following a reasonable period of time after the work was first published, provided that clear reference is made to the source of the first publication of the work.

This publication is distributed under The Association of Universities in the Netherlands (VSNU) 'Article $25 \mathrm{fa}$ implementation' project. In this project research outputs of researchers employed by Dutch Universities that comply with the legal requirements of Article $25 \mathrm{fa}$ of the Dutch Copyright Act are distributed online and free of cost or other barriers in institutional repositories. Research outputs are distributed six months after their first online publication in the original published version and with proper attribution to the source of the original publication.

You are permitted to download and use the publication for personal purposes. All rights remain with the author(s) and / or copyright owner(s) of this work. Any use of the publication or parts of it other than authorised under article $25 \mathrm{fa}$ of the Dutch Copyright act is prohibited. Wageningen University \& Research and the author(s) of this publication shall not be held responsible or liable for any damages resulting from your (re)use of this publication.

For questions regarding the public availability of this publication please contact openscience.library@wur.nl 


\title{
Spoilage evaluation, shelf-life prediction, and potential spoilage organisms of tropical brackish water shrimp (Penaeus notialis) at different storage temperatures
}

\author{
D. Sylvain Dabadé ${ }^{\text {a, b }}$, Heidy M.W. den Besten ${ }^{\text {b, * }}$, Paulin Azokpota ${ }^{\text {a }}$, M.J. Robert Nout ${ }^{\text {b }}$, \\ D. Joseph Hounhouigan ${ }^{\mathrm{a}}$, Marcel H. Zwietering ${ }^{\mathrm{b}}$ \\ ${ }^{a}$ Laboratoire de Biochimie Microbienne et de Biotechnologie Alimentaire, University of Abomey-Calavi, 01 B.P. 526 Cotonou, Benin \\ ${ }^{\mathrm{b}}$ Laboratory of Food Microbiology, Wageningen University, P.O. Box 17, 6700 AA Wageningen, The Netherlands
}

\section{A R T I C L E I N F O}

\section{Article history:}

Received 17 June 2014

Received in revised form

14 October 2014

Accepted 7 November 2014

Available online 17 December 2014

\section{Keywords:}

Shrimp quality

Microbiological change

TVBN

Sensory rejection

Shelf-life prediction

\begin{abstract}
A B S T R A C T
Maintaining the freshness of shrimp is a concern to shrimp stakeholders. To improve shrimp quality management, it is of importance to evaluate shrimp spoilage characteristics. Therefore, microbiological, sensory, and chemical changes of naturally contaminated tropical brackish water shrimp (Penaeus notialis) during storage at $28^{\circ} \mathrm{C}, 7^{\circ} \mathrm{C}$ and $0^{\circ} \mathrm{C}$ were assessed. $\mathrm{H}_{2} \mathrm{~S}$-producing bacteria were the dominant group of microorganisms at $28{ }^{\circ} \mathrm{C}$ and $7{ }^{\circ} \mathrm{C}$ whereas Pseudomonas spp. were dominant at $0{ }^{\circ} \mathrm{C}$. Total volatile basic nitrogen and trimethylamine correlated well $\left(R^{2}>0.90\right)$ with the sensory scores. An empirical model to predict the shelf-life of naturally contaminated tropical shrimp as a function of storage temperature was developed. Specific groups of organisms were isolated at the sensory rejection times and assessed for spoilage potential in shrimps of which the endogenous flora was heat inactivated. Isolates capable of producing strong off-odor identified by $16 \mathrm{~S}$ rRNA sequencing were mainly lactic acid bacteria (LAB) and Enterobacteriaceae at $28{ }^{\circ} \mathrm{C}$ or $7{ }^{\circ} \mathrm{C}$ and Pseudomonas spp. and LAB at $0{ }^{\circ} \mathrm{C}$. The study contributes to the knowledge about tropical shrimp spoilage and provides a basis for the development of methods and tools to improve shrimp quality management.
\end{abstract}

() 2014 Elsevier Ltd. All rights reserved.

\section{Introduction}

Shrimp is one of the most traded and consumed aquatic products worldwide (Chen et al., 2013; Wan Norhana et al., 2010). In Benin (West Africa), shrimps are caught from brackish waters (lakes and lagoons), processed and sold in the local market or exported (Dabadé et al., 2014). Shrimp is prone to deterioration because of its high content of free amino-acids and other soluble nonnitrogenous substances, which can serve as easily digestible nutrients for microbial growth (Zeng et al., 2005). However, only a few members of the microbial community of freshly caught or processed seafood, the so-called specific spoilage organisms (SSOs) really contribute to the seafood spoilage (Gram and Dalgaard, 2002). The identification of bacteria that are responsible for spoilage requires sensory, microbiological and chemical studies (Gram and Huss, 1996). Specific spoilage organisms produce

\footnotetext{
* Corresponding author. Tel.: +31317 483213.

E-mail address: Heidy.denBesten@wur.nl (H.M.W. den Besten).
}

various volatile compounds, some of which could function as indicators of spoilage. Volatile amines, including trimethylamine (TMA), ammonia $\left(\mathrm{NH}_{3}\right)$ and dimethylamine (DMA) represent total volatile basic nitrogen (TVB-N), which is the most widely used parameter to reveal microbiological spoilage of seafood (Chan et al., 2006; Pacquit et al., 2007). Heinsz et al. (1988) reported that Acinetobacter spp. were the main organisms responsible for the spoilage of shrimps (Penaeus aztecus) harvested from Georgia coastal waters. The dominant microorganisms in shrimps (Penaeus merguiensis) harvested from Pakistan at sensory rejection times were found to be Moraxella spp. at low storage temperatures $\left(0-10{ }^{\circ} \mathrm{C}\right)$ and Vibrio spp. at high storage temperatures $\left(15-35^{\circ} \mathrm{C}\right)$ (Shamshad et al., 1990). Assessing the spoilage pattern of five species of shrimps, Chinivasagam et al. (1996) found that Pseudomonas fragi was the main spoiler of iced-stored tropical shrimps, and Shewanella putrefaciens, the dominant microorganism in tropical shrimps stored in ice slurry. All these reports on shrimp spoilage showed that even for the same seafood product, spoilage may develop differently, depending on geographical origin and other unknown factors interacting with microbial growth (Gram 
and Huss, 1996). To our knowledge, there is no report on specific spoilage organisms of tropical shrimp caught from brackish waters in Africa. The aim of this work was to (i) evaluate the quality changes of shrimps caught from brackish waters stored at different temperatures and the effect of storage temperature on their shelflife, (ii) assess the spoilage potential of bacterial strains isolated at sensory rejection time, and (iii) identify the major spoilage bacteria.

\section{Materials and methods}

\subsection{Study with naturally contaminated shrimp}

\subsubsection{Samples preparation and storage conditions}

Freshly caught shrimps (Penaeus notialis) were collected from Lake Nokoue and Lake Aheme in Benin (West Africa), which are the most important shrimp fishing areas in Benin. The average weights of shrimps from Lake Nokoue and Lake Aheme were $12 \pm 2 \mathrm{~g}$ and $20 \pm 3 \mathrm{~g}$ per shrimp respectively. Immediately after collection, samples were cooled with ice and transferred to the laboratory within $2 \mathrm{~h}$. Packs of shrimps were put in polyethylene bags and stored at $0{ }^{\circ} \mathrm{C}, 7{ }^{\circ} \mathrm{C}$ and $28{ }^{\circ} \mathrm{C}$. For $0{ }^{\circ} \mathrm{C}$ storage, the method by Shamshad et al. (1990) was used. Shrimps were put in ice in a plastic container with drain holes. The plastic container was put on another container and kept at $4{ }^{\circ} \mathrm{C}$. The ratio of shrimp to ice was approximately $1: 3$. Shrimps were re-iced daily to maintain the same ratio. For $7^{\circ} \mathrm{C}$ and $28^{\circ} \mathrm{C}$ storage, shrimps were stored in Sanyo MIR-153 refrigerated and Memmert incubators respectively. For all storage temperatures, thermochron iButton (DS 1921G) devices were placed in some shrimp samples to record temperatures during storage. At appropriate time intervals, three packs of shrimp were taken out and each pack was used for microbiological, chemical and sensory analyses to obtain triplicate analysis per sampling time point. All microbiological media and chemicals used were from OXOID and SIGMA, respectively.

\subsubsection{Microbiological analysis}

Whole shrimps (2-3 individuals per pack) were aseptically cut into small pieces, after which a $25 \mathrm{~g}$ sample was transferred aseptically to a stomacher bag and diluted 10 times in physiological saline peptone solution $(0.85 \% \mathrm{NaCl}, 0.1 \%$ peptone $)$. The mixture was homogenized for $60 \mathrm{~s}$ using a stomacher (Seward Laboratory Stomacher 400, England) to get the first dilution from which successive decimal dilutions were prepared. Total Viable Counts (TVC) measured as aerobic plate counts, and $\mathrm{H}_{2} \mathrm{~S}$-producing bacteria were enumerated on double layered plates of Iron Agar (IA) supplemented with $0.04 \% \mathrm{~L}$-cysteine and incubated at $25{ }^{\circ} \mathrm{C}$ for $72 \mathrm{~h}$ as described by Gram et al. (1987). Black colonies were counted as $\mathrm{H}_{2} \mathrm{~S}$-producing bacteria and TVC as the sum of black and white colonies as previously described (Martínez-Alvarez et al., 2009; Mai et al., 2011; Broekaert et al., 2011; Giuffrida et al., 2013). Enterobacteriaceae were enumerated on double-layered plates of violet red bile glucose (VRBG) medium and incubated at $37{ }^{\circ} \mathrm{C}$ for $24 \mathrm{~h}$. Pseudomonas spp. were enumerated on spread plates of Pseudomonas agar base supplemented with cetrimide, fucidin, and cephaloridine (CFC) at $25{ }^{\circ} \mathrm{C}$ for $48 \mathrm{~h}$. Lactic acid bacteria (LAB) were enumerated on double-layered plates of de Man, Rogosa and Sharp agar (MRSA) incubated at $30{ }^{\circ} \mathrm{C}$ for $72 \mathrm{~h}$. For the double-layered plates, $1 \mathrm{~mL}$ of the appropriate dilution was inoculated into a Petri dish, then approximately $15-\mathrm{mL}$ of the molten $\left(45^{\circ} \mathrm{C}\right)$ medium was poured into the Petri dish. After setting, the Petri dish was overlaid with approximately $10-\mathrm{mL}$ of the same molten medium.

\subsubsection{Chemical analysis}

Total volatile basic nitrogen (TVBN), trimethylamine (TMA) and $\mathrm{pH}$ were determined. TVBN (mg/100 g shrimp) was measured using the method recommended by the European Commission (Commission regulation (EC) No 2074/2005). Briefly, $10 \mathrm{~g}$ of ground shrimp were homogenized with $90 \mathrm{~mL} 6 \%$ perchloric acid (SIGMA) solution for $2 \mathrm{~min}$. After filtering, $50 \mathrm{~mL}$ of the extract were alkalinized with $20 \%$ sodium hydroxide, and submitted to steam distillation. The distillation apparatus was set to produce approximately $100 \mathrm{~mL}$ of distillate in $10 \mathrm{~min}$. The distillation ended after exactly $10 \mathrm{~min}$, allowing the same distillation rate for all the samples. The volatile base components absorbed by boric acid solution (3\%) in laboratory standard glassware (beaker, flask) were determined by titration using hydrochloric acid solution (0.01 mol). To determine TMA, $20 \mathrm{~mL}$ of $35 \%$ formaldehyde (an alkaline binding mono and diamine) was added to $25 \mathrm{~mL}$ perchloric acid shrimp extract prior to the following steps. Thus, TMA was the only volatile and measurable amine (Magnusson et al., 2006; Malle and Tao, 1987). To determine the pH, $20 \mathrm{~mL}$ of distilled water were added to $10 \mathrm{~g}$ of ground shrimp. The mixture was homogenized and the $\mathrm{pH}$ was measured in duplicate using a $\mathrm{pH}$ meter (InoLab 730).

\subsubsection{Sensory analysis}

Ten panelists experienced in shrimp freshness evaluation carried out the sensory analysis. At each sensory session, the panelist evaluated one piece of whole shrimp from each pack of shrimps. Samples of freshly thawed shrimps were also included to reduce the risk of panelists guessing the development in sensory score (Mejlholm et al., 2005). The odor of raw shrimps was evaluated using a scoring scale with three categories (Dalgaard et al., 1993; Mejlholm et al., 2008; Argyri et al., 2010) corresponding to 1 = fresh (shrimp without any off-odor), 2 = marginal (shrimp having slight off-odor but still being acceptable) and $3=$ spoiled (shrimp producing strong off-odor). Time of sensory rejection was defined as the time when at least $50 \%$ of the panelists evaluated samples to be in category 3 .

\subsubsection{Effect of storage temperature on the shelf-life of naturally contaminated shrimp}

Data on the rates of spoilage determined as the reciprocal of shelf-life (RS, day ${ }^{-1}$ ) from both lakes were combined and three empirical models: exponential model (1) Ratkowsky model (2) (Ratkowsky et al., 1982) and Arrhenius model (3) were fitted to the combined RS-data.

$$
\begin{aligned}
& \mathrm{RS}=b_{1} \times \exp (a \times T) \\
& \mathrm{RS}=b_{2}^{2} \times\left(T-T_{\text {min }}\right)^{2} \\
& \mathrm{RS}=b_{3} \times \exp \left(\frac{-E_{a}}{R \times K}\right)
\end{aligned}
$$

With $T$, the storage temperature $\left({ }^{\circ} \mathrm{C}\right) ; R$, the gas constant 8.314 $\left(\mathrm{J} \mathrm{mol}^{-1} \mathrm{~K}^{-1}\right)$; $K$, temperature in Kelvin. $b_{i}, a, T_{\min }$ and $E_{a}$ are coefficients to be estimated.

The variance of RS was high at high storage temperatures. Therefore, RS-data were In-transformed to stabilize the variance over the temperature range. The performance of the three models was assessed by fitting the models to the ln-transformed data and comparing the root mean square error of the model (RMSE $\left.E_{\text {model }}\right)$ as described by Den Besten et al. (2006).

$R M S E_{\text {model }}=\sqrt{\frac{\sum\left(\text { observed }_{i}-\text { fitted }_{i}\right)^{2}}{n-s}}$ 


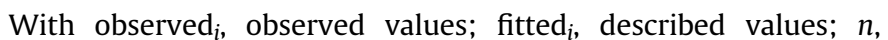
number of data points; $s$, number of parameters of the model.

\subsection{Spoilage potential assessment}

At sensory rejection times, two counted plates (20-200 colonies per plate) were randomly selected per group of microorganisms at each storage temperature. At least 5 colonies per plate, representative of the variability in shape, color and size of all colonies in the plate, were selected. The colonies were checked for purity on MRSA for lactic acid bacteria and on tryptone soya agar (TSA) for other groups of microorganisms. Presumptive tests namely Gram staining and catalase test, oxidase and glucose fermentation test, and oxidase test were performed on lactic acid bacteria, Enterobacteriaceae, and Pseudomonas spp., respectively as previously described (Zheng et al., 2012; Rodríguez-Calleja et al., 2012). Pure cultures of isolated colonies were inoculated to freshly caught shrimp of which the endogenous flora was heat inactivated at $100{ }^{\circ} \mathrm{C}$ for $30 \mathrm{~min}$. The inoculation was approximately $10^{5} \mathrm{CFU} / \mathrm{g}$ of shrimp. The samples were stored as described in 2.1.1 at the temperature of initial isolation. The ability of the inoculated culture to produce off-odor was evaluated by the same panelists as described in 2.1.4. Strains deemed to produce strong off-odor by at least $50 \%$ of the panelists were identified following the procedure described below.

\subsection{Identification of spoilage bacteria}

Isolates capable of producing strong off-odor were grown on TSA plates overnight. The protocol described in the genomic DNA purification kit (Promega Corporation) was used to extract DNA. The DNA extracts were used to amplify the 16S rRNA gene with polymerase chain reaction (PCR) using the thermocycler GeneAmp PCR system 9700 (Applied Biosystems). The PCR was performed using 8F (5'-AGA GTT TGA TCC TGG CTC AG-3') and 1522R (5'-AAG GAG GTG ATC CAG CCG CA-3') universal primers with PCR conditions as follows: initial denaturation of double stranded DNA at $94{ }^{\circ} \mathrm{C}$ for $5 \mathrm{~min}$, then 35 amplification cycles with denaturation at $94{ }^{\circ} \mathrm{C}$ for $20 \mathrm{~s}$, primer annealing at $56{ }^{\circ} \mathrm{C}$ for $20 \mathrm{~s}$, and extension at $72{ }^{\circ} \mathrm{C}$ for $1 \mathrm{~min}$, finally an extension at $72{ }^{\circ} \mathrm{C}$ for $7 \mathrm{~min}$ followed by cooling at $4{ }^{\circ} \mathrm{C}$. The PCR products were sequenced at GATC Biotech (Germany). The DNA Baser Sequence Assembler v3.5.2 (2012) (http://www.DnaBaser.com) was used to assemble the forward and reverse sequences. The sequences were checked with Bellerophon's chimera detection program (Hubert et al., 2004) and compared against the GenBank database using the basic local alignment search tool (BLAST) (Altschul et al., 1990). The sequences were deposited in the GenBank database under the accession numbers KJ626227-KJ626264.

\section{Results}

The actual storage temperatures recorded were $27.8 \pm 0.4{ }^{\circ} \mathrm{C}$; $7.1 \pm 0.3{ }^{\circ} \mathrm{C}$, and $0.1 \pm 0.3^{\circ} \mathrm{C}$ during storage at $28^{\circ} \mathrm{C}, 7^{\circ} \mathrm{C}$, and $0{ }^{\circ} \mathrm{C}$ respectively. The results obtained in the present work with shrimps from lake Nokoue and lake Aheme were rather similar. Therefore, we present here the results of shrimps from lake Aheme and data from lake Nokoue are included as supplemental data. However, the identified spoilage organisms and data used for shelf-life prediction were from shrimps caught in both lakes.

\subsection{Microbiological analysis}

The evolution of TVC, $\mathrm{H}_{2} \mathrm{~S}$-producing bacteria, Pseudomonas spp., Enterobacteriaceae, and LAB concentration during shrimp storage at different temperatures is shown in Fig. 1. The initial concentrations of the different groups of microorganisms varied between $2.7 \log \mathrm{CFU} / \mathrm{g}$ (Enterobacteriaceae) and $5.5 \log \mathrm{CFU} / \mathrm{g}$ (TVC).

During storage at $28{ }^{\circ} \mathrm{C}$, TVC increased slowly the first $6 \mathrm{~h}$, and then rapidly increased to $8.9 \mathrm{log} \mathrm{CFU} / \mathrm{g}$ after $13 \mathrm{~h}$ of storage. $\mathrm{H}_{2} \mathrm{~S}$ producing bacteria were the dominant group of microorganisms at the end of storage with a concentration of $8.2 \mathrm{log} \mathrm{CFU} / \mathrm{g}$. Pseudomonas spp., Enterobacteriaceae, and LAB also grew throughout the
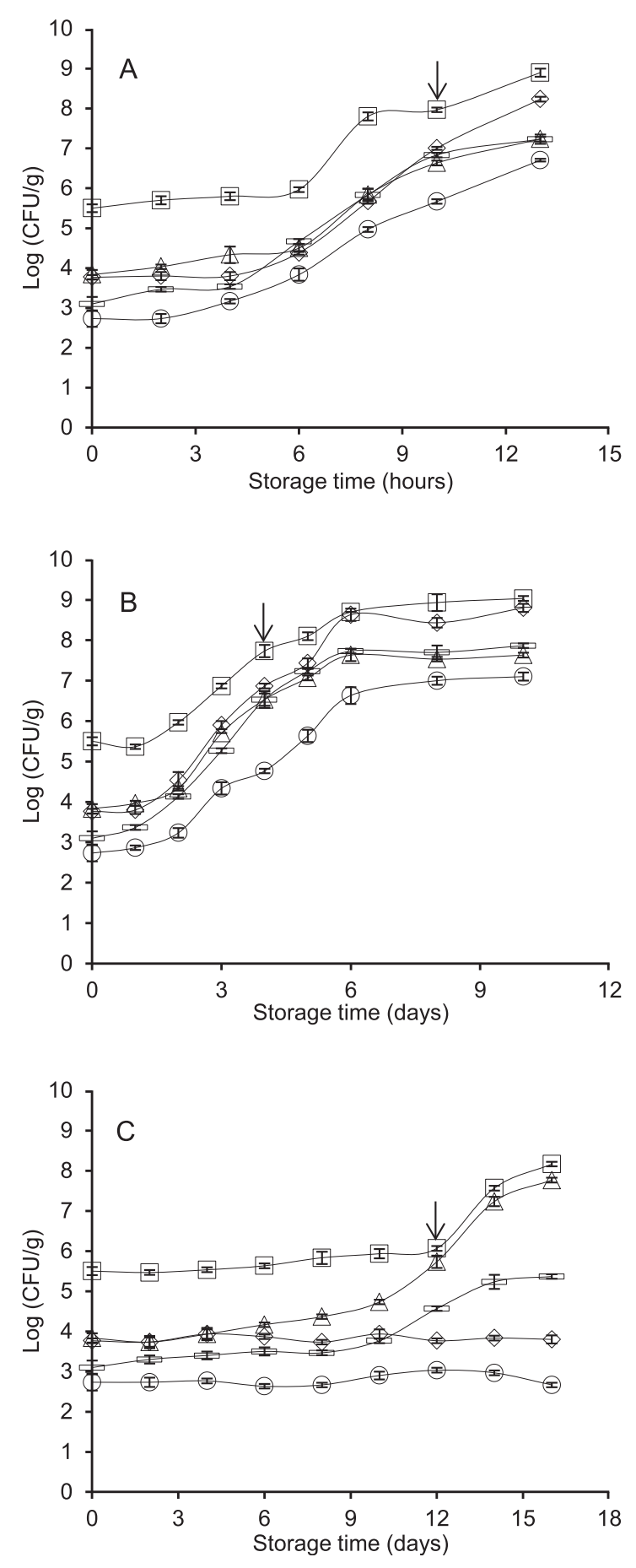

Fig. 1. Evolution of total viable counts $(\square), \mathrm{H}_{2} \mathrm{~S}$-producing bacteria $(\diamond)$, Pseudomonas spp. $(\Delta)$, Enterobacteriaceae $(O)$, and lactic acid bacteria $(\hookrightarrow)$ of shrimp stored at $28^{\circ} \mathrm{C}(\mathrm{A}), 7^{\circ} \mathrm{C}(\mathrm{B})$, and $0{ }^{\circ} \mathrm{C}(\mathrm{C})$. Arrow indicates sensory rejection time. Bars represent the standard deviation of three independent samples. 
storage time reaching 7.2, 6.7, and $7.2 \log \mathrm{CFU} / \mathrm{g}$ respectively at the end of storage.

The growth pattern of the enumerated bacteria in the samples stored at $7{ }^{\circ} \mathrm{C}$ was similar but slower than the one observed at $28{ }^{\circ} \mathrm{C}$. After the first day of storage, total viable counts slowly increased to $9.0 \log \mathrm{CFU} / \mathrm{g}$ by the end of storage. $\mathrm{H}_{2} \mathrm{~S}$-producing bacteria were also the dominant group of microorganisms at the
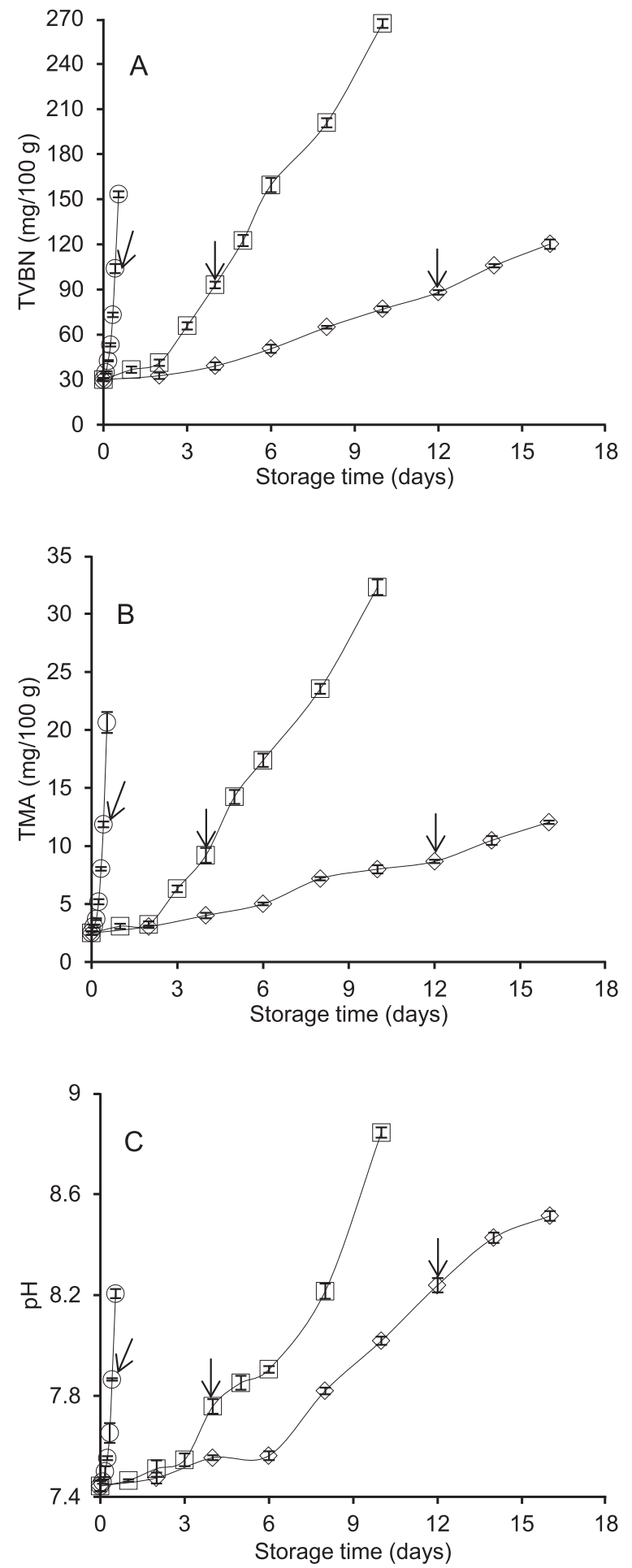

Fig. 2. Evolution of total volatile basic nitrogen (TVBN) (A), trimethylamine (TMA) (B), $\mathrm{pH}(\mathrm{C})$ of shrimp stored at $28^{\circ} \mathrm{C}(\mathrm{O}), 7^{\circ} \mathrm{C}(\square)$, and $0{ }^{\circ} \mathrm{C}(\diamond)$. Arrow indicates sensory rejection time. Bars represent the standard deviation of three independent samples. end of storage at $7{ }^{\circ} \mathrm{C}$ reaching $8.8 \log \mathrm{CFU} / \mathrm{g}$. Pseudomonas spp. counts increased to their maximal concentration of $7.6 \log$ CFU/g after 6 days of storage and remained constant until the end of storage. Enterobacteriaceae and LAB concentrations increased to 7.1 and $7.9 \log \mathrm{CFU} / \mathrm{g}$ respectively at the end of storage time.

In samples stored at $0{ }^{\circ} \mathrm{C}$, TVC proliferated slowly the first 10 days of storage. Afterward, they increased to $8.2 \mathrm{log} \mathrm{CFU} / \mathrm{g}$ at the end of storage time. Pseudomonas spp. were the dominant group of microorganism during storage at $0{ }^{\circ} \mathrm{C}$. At the end of storage, Pseudomonas spp. counts increased to $7.4 \mathrm{log} \mathrm{CFU} / \mathrm{g}$. LAB counts increased to the level of $5.4 \log \mathrm{CFU} / \mathrm{g}$ at the end of storage time. Throughout the storage time, $\mathrm{H}_{2} \mathrm{~S}$-producing bacteria and Enterobacteriaceae counts remained almost constant.

\subsection{Chemical changes}

The evolution of TVBN, TMA and $\mathrm{pH}$ values in shrimp samples stored at $28{ }^{\circ} \mathrm{C}, 7{ }^{\circ} \mathrm{C}$, and $0{ }^{\circ} \mathrm{C}$ is depicted in Fig. $2 \mathrm{~A}, \mathrm{~B}$ and $\mathrm{C}$ respectively. The initial values of TVBN, TMA and $\mathrm{pH}$ were $30.1 \mathrm{mg} /$ $100 \mathrm{~g}, 2.5 \mathrm{mg} / 100 \mathrm{~g}$, and 7.4 respectively. TVBN, TMA and pH values increased throughout the storage. As expected, the rate of the chemical indicator change was higher at high temperature than at low temperature. At the sensory rejection times, TVBN values ranged from 88 to $104 \mathrm{mg} / 100 \mathrm{~g}$ and TMA values, from 9 to $12 \mathrm{mg}$ / $100 \mathrm{~g}$.

\subsection{Sensory analysis}

The results of shrimp sensory evaluation are presented in Table 1. At the beginning of storage time, shrimp samples did not produce any off-odor according to $96.7 \%$ (mean percentage of three packs of shrimps, each assessed by 10 panelists) of the panelists. The percentage of the panelists evaluating the shrimp samples as producing strong off-odor increased with storage time. The sensory rejection time defined as the time when at least $50 \%$ of the panelists evaluate shrimp to produce strong off-odor was $10 \mathrm{~h}$ at $28^{\circ} \mathrm{C}, 4 \mathrm{~d}$ at $7{ }^{\circ} \mathrm{C}$, and $12 \mathrm{~d}$ at $0{ }^{\circ} \mathrm{C}$.

Table 1

Shrimp off-odor evaluation (in \% of panelists) during storage at $28{ }^{\circ} \mathrm{C}(\mathrm{A}), 7^{\circ} \mathrm{C}(\mathrm{B})$, and $0{ }^{\circ} \mathrm{C}(\mathrm{C})$.

\begin{tabular}{|c|c|c|c|c|c|c|c|c|c|}
\hline \multicolumn{10}{|l|}{ A } \\
\hline \multirow[t]{2}{*}{ Odor evaluation } & \multicolumn{9}{|c|}{ Storage time (hours) } \\
\hline & 0 & \multicolumn{2}{|c|}{2} & 4 & 6 & 8 & \multicolumn{2}{|r|}{10} & 13 \\
\hline No off-odor & \multicolumn{2}{|c|}{96.7} & 93.3 & 83.3 & 66.7 & \multicolumn{2}{|c|}{10.0} & 0 & 0 \\
\hline Slight off-odor & \multicolumn{2}{|c|}{3.3} & 6.7 & 16.7 & 33.0 & \multicolumn{2}{|c|}{83.3} & 46.7 & 6.7 \\
\hline Strong off-odor & \multicolumn{2}{|l|}{0} & 0 & 0 & 0 & \multicolumn{2}{|c|}{6.7} & 53.3 & 93.3 \\
\hline \multicolumn{10}{|l|}{ B } \\
\hline \multirow[t]{2}{*}{ Odor evaluation } & \multicolumn{9}{|c|}{ Storage time (days) } \\
\hline & 0 & 1 & 2 & 3 & 4 & 5 & 6 & 8 & 10 \\
\hline No off-odor & 96.7 & 86.7 & 80.0 & 10.0 & 0 & 0 & 0 & 0 & 0 \\
\hline Slight off-odor & 3.3 & 13.3 & 20.0 & 66.7 & 43.0 & 30.0 & 6.7 & 0 & 0 \\
\hline Strong off-odor & 0 & 0 & 0 & 23.3 & 56.7 & 70.0 & 93.3 & 100 & 100 \\
\hline \multicolumn{10}{|l|}{ C } \\
\hline \multirow[t]{2}{*}{ Odor evaluation } & \multicolumn{9}{|c|}{ Storage time (days) } \\
\hline & 0 & 2 & 4 & 6 & 8 & 10 & 12 & 14 & 16 \\
\hline No off-odor & 96.7 & 93.3 & 90.0 & 30.0 & 10.0 & 6.7 & 6.7 & 0 & 0 \\
\hline Slight off-odor & 3.3 & 6.7 & 10.0 & 70.0 & 86.7 & 83.3 & 43.0 & 40.0 & 33.3 \\
\hline Strong off-odor & 0 & 0 & 0 & 0 & 3.3 & 10.0 & 50.0 & 60.0 & 66.7 \\
\hline
\end{tabular}

Values in boldface indicate sensory rejection times. 
3.4. Relationship between chemical indicators and microbial concentration or sensory scores

At all storage temperatures, from the beginning of storage until the sensory rejection time, a good correlation $\left(R^{2}>0.90\right)$ was found between TVBN or TMA production and the means of sensory scores by the 10 panelists at each sensory session (Fig. $3 \mathrm{~A}$ and $\mathrm{B}$ ). The
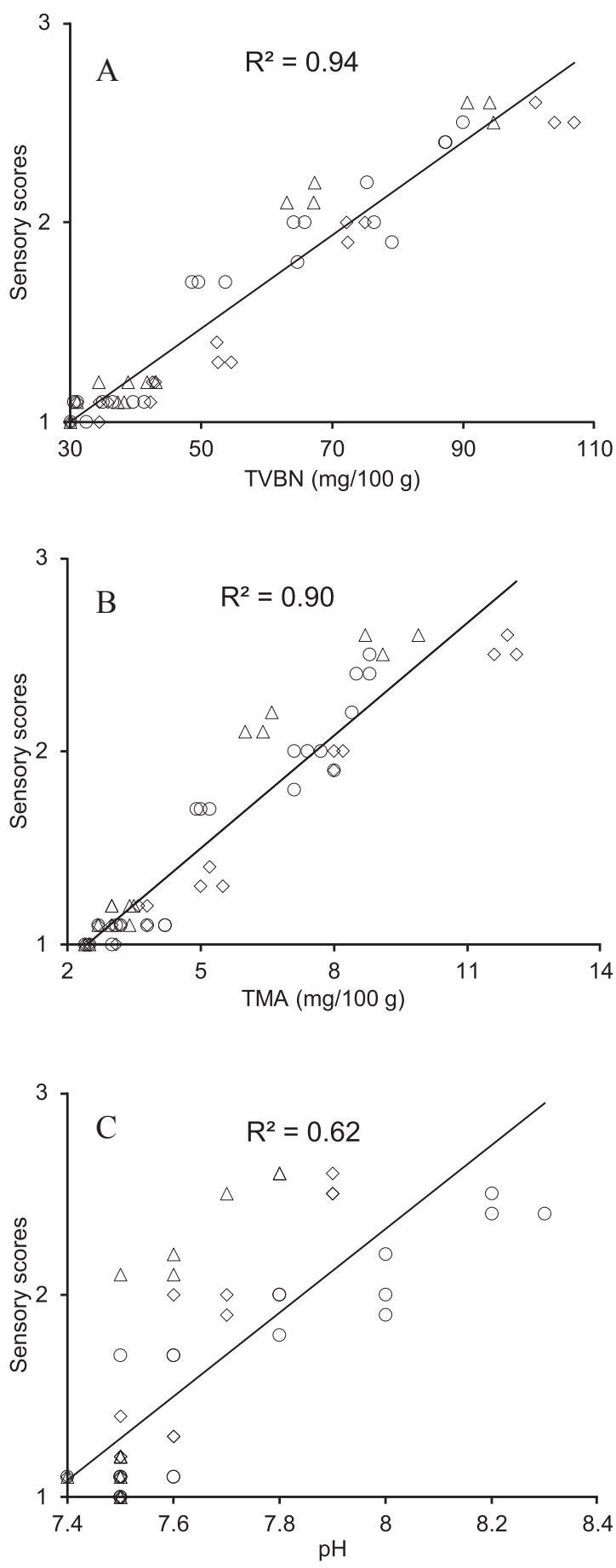

Fig. 3. Relationship between sensory scores and total volatile basic nitrogen (TVBN) (A), trimethylamine (TMA) (B), and $\mathrm{pH}(\mathrm{C})$ values from the beginning of shrimp storage at $28{ }^{\circ} \mathrm{C}(\diamond), 7{ }^{\circ} \mathrm{C}(\Delta)$ and $0{ }^{\circ} \mathrm{C}(\mathrm{O})$ until the sensory rejection time. Sensory scores: 1 = shrimp without any off-odor, 2 = shrimp having slight off-odor but still being acceptable and $3=$ shrimp producing strong off-odor. The average of 10 panelists was used. correlation between $\mathrm{pH}$ values and the sensory scores was lower (Fig. 3C). A good but lower correlation $\left(R^{2}>0.85\right)$ was found between TVBN production and the log counts of TVC or the dominant group of microorganisms at the different storage temperatures (data not shown).

\subsection{Effect of temperature on spoilage rate and shelf-life prediction}

The root mean square error ( $\left.R M S E_{\text {model }}\right)$ of exponential, Ratkowsky, and Arrhenius models were 0.18, 0.21, and 0.15, respectively. The best fitting model was the Arrhenius model and the fitted parameters $E_{a}$ and $\ln b_{3}$ were $80.2 \pm 4.5 \mathrm{~kJ} \mathrm{~mol}^{-1}(95 \% \mathrm{CI})$ and $33.03 \pm 1.89(95 \% \mathrm{CI})$, respectively. The effect of temperature on the rate of spoilage is shown in Fig. 4.

With the estimated parameters $E_{a}$ and $b_{3}\left(2.21 \times 10^{14}\right)$ the shelf-life of tropical brackish water shrimp $P$. notialis could be predicted at a given storage temperature using equation (5)

Shelf life $($ days $)=4.5 \times 10^{-15} \times \exp \left(\frac{9650}{K}\right)$

With $K$, storage temperature in Kelvin.

\subsection{Spoilage potential assessment and identification of spoilage bacteria}

A total of 38 out of 189 strains isolated at sensory rejection time and assessed for spoilage potential (their ability to produce offodor) were detected to produce strong off-odor. The spoilage assessment results and the identity of isolates capable of producing strong off-odor are shown in Table 2. The strongest off-odor producers belonged to the Enterobacteriaceae and lactic acid bacteria at $28{ }^{\circ} \mathrm{C}$ and $7{ }^{\circ} \mathrm{C}$, whereas at $0{ }^{\circ} \mathrm{C}$ the off-odor producing bacteria were Pseudomonas spp. and lactic acid bacteria. It should be noted that all the black colonies isolated from iron agar were identified as members of lactic acid bacteria. Morganella morganii, a member of Enterobacteriaceae, was twice isolated from Pseudomonas agar in this study.

\section{Discussion}

The present study aimed at evaluating the quality change of tropical brackish water shrimp (P. notialis). The initial total aerobic counts obtained in this study (5.5 log CFU/g) are higher than those

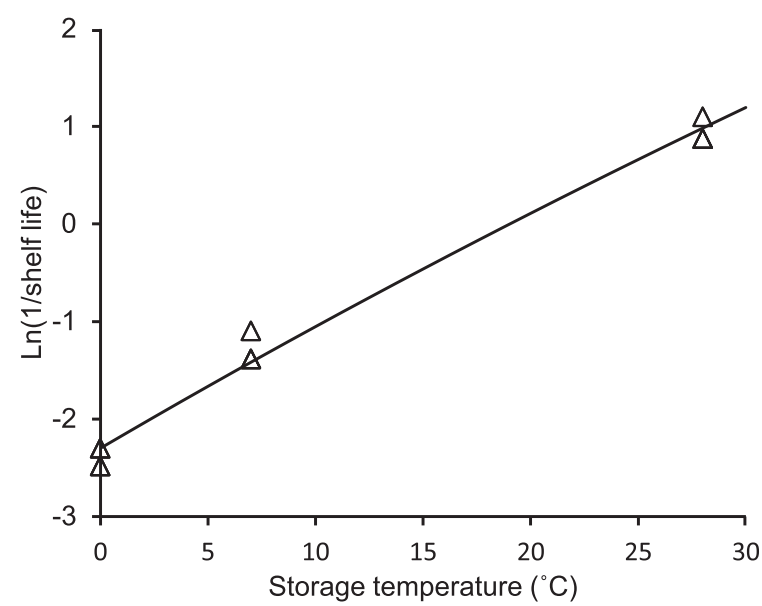

Fig. 4. Shrimp shelf-life modeled with Arrhenius model using data from lake Nokoue and lake Aheme. Legend: time is in days. 
Table 2

Spoilage potential assessment and identities of isolates capable of producing strong off-odor at $28^{\circ} \mathrm{C}, 7^{\circ} \mathrm{C}$ and $0{ }^{\circ} \mathrm{C}$.

\begin{tabular}{|c|c|c|c|c|c|c|}
\hline $\mathrm{T}^{\mathrm{a}}\left({ }^{\circ} \mathrm{C}\right)$ & Culture media & $\begin{array}{l}\text { Number of } \\
\text { isolates tested }\end{array}$ & $\begin{array}{l}\text { Number of isolates } \\
\text { producing strong } \\
\text { off-odor }\end{array}$ & $\begin{array}{l}\text { \% Similarity and GeneBank } \\
\text { closest relatives }\end{array}$ & $\begin{array}{l}\text { GenBank given } \\
\text { accession number }\end{array}$ & $\begin{array}{l}\% \text { of panelists judging } \\
\text { the isolates to produce } \\
\text { strong off-odor }(n=10)\end{array}$ \\
\hline \multirow[t]{21}{*}{28} & \multirow[t]{5}{*}{ Iron Agar (black colonies) } & \multirow[t]{5}{*}{15} & \multirow[t]{5}{*}{5} & 99\% Lactococcus garvieae & KJ626245 & 80 \\
\hline & & & & 99\% Lactococcus garvieae & KJ626247 & 90 \\
\hline & & & & 99\% Lactococcus garvieae & KJ626248 & 80 \\
\hline & & & & $99 \%$ Lactococcus garvieae ${ }^{\mathrm{e}}$ & KJ626234 & 80 \\
\hline & & & & 97\% Enterococcus aquimarinus & KJ626244 & 70 \\
\hline & \multirow[t]{3}{*}{ Iron Agar (white colonies) } & \multirow[t]{3}{*}{16} & \multirow[t]{3}{*}{3} & 99\% Morganella morganii & KJ626255 & 60 \\
\hline & & & & 99\% Lactococcus garvieae & KJ626257 & 80 \\
\hline & & & & $97 \%$ Acinetobacter calcoaceticus ${ }^{\mathrm{e}}$ & KJ626230 & 70 \\
\hline & $\mathrm{PSA}^{\mathrm{b}}$ & 14 & 1 & 99\% Morganella morganii & KJ626253 & 50 \\
\hline & \multirow[t]{11}{*}{ VRBGA $^{\mathrm{c}}$} & \multirow[t]{11}{*}{15} & \multirow[t]{11}{*}{11} & 99\% Klebsiella pneumoniae & KJ626250 & 70 \\
\hline & & & & 99\% Klebsiella pneumoniae & KJ626261 & 80 \\
\hline & & & & 99\% Klebsiella pneumonia & KJ626227 & 70 \\
\hline & & & & $100 \%$ Klebsiella variicola ${ }^{\mathrm{e}}$ & KJ626231 & 80 \\
\hline & & & & 99\% Escherichia fergusonii & KJ626246 & 80 \\
\hline & & & & 99\% Escherichia fergusonii & KJ626262 & 90 \\
\hline & & & & 99\% Escherichia fergusonii & KJ626263 & 80 \\
\hline & & & & 99\% Shigella sonnei ${ }^{\mathrm{e}}$ & KJ626232 & 80 \\
\hline & & & & $97 \%$ Proteus vulgaris & KJ626254 & 80 \\
\hline & & & & 99\% Escherichia fergusonii & KJ626264 & 70 \\
\hline & & & & $99 \%$ Providencia vermicola $^{\mathrm{e}}$ & KJ626236 & 60 \\
\hline & MRSA $^{\mathrm{d}}$ & 12 & 0 & - & - & - \\
\hline \multirow[t]{13}{*}{7} & \multirow[t]{5}{*}{ Iron Agar (black colonies) } & \multirow[t]{5}{*}{12} & \multirow[t]{5}{*}{5} & 99\% Vagococcus fluvialis & KJ626239 & 60 \\
\hline & & & & $99 \%$ Vagococcus fluvialis & KJ626241 & 60 \\
\hline & & & & $99 \%$ Vagococcus fluvialis & KJ626242 & 60 \\
\hline & & & & $99 \%$ Vagococcus fluvialis & KJ626243 & 70 \\
\hline & & & & 99\% Enterococcus faecalis & KJ626240 & 70 \\
\hline & \multirow[t]{2}{*}{ Iron Agar (white colonies) } & \multirow[t]{2}{*}{13} & \multirow[t]{2}{*}{2} & 99\% Proteus mirabilis & KJ626258 & 70 \\
\hline & & & & 99\% Acinetobacter johnsonii ${ }^{\mathrm{e}}$ & KJ626237 & 60 \\
\hline & PSA & 12 & 1 & 99\% Morganella morganii & KJ626252 & 60 \\
\hline & \multirow[t]{4}{*}{ VRBGA } & \multirow[t]{4}{*}{11} & \multirow[t]{4}{*}{4} & 99\% Proteus penneri & KJ626233 & 80 \\
\hline & & & & 99\% Proteus penneri ${ }^{\mathrm{e}}$ & KJ626235 & 70 \\
\hline & & & & 99\% Proteus penneri ${ }^{\mathrm{e}}$ & KJ626228 & 70 \\
\hline & & & & 99\% Proteus penneri ${ }^{\mathrm{e}}$ & KJ626229 & 80 \\
\hline & MRSA & 11 & 1 & 99\% Weissella cibaria & KJ626260 & 70 \\
\hline \multirow[t]{9}{*}{0} & Iron Agar (black colonies) & 12 & 0 & - & - & - \\
\hline & \multirow[t]{3}{*}{ Iron Agar (white colonies) } & \multirow[t]{3}{*}{13} & \multirow[t]{3}{*}{3} & 99\% Pseudomonas gessardii & KJ626259 & 100 \\
\hline & & & & $99 \%$ Enterococcus faecalis & KJ626256 & 80 \\
\hline & & & & $99 \%$ Carnobacterium maltaromaticum & KJ626238 & 100 \\
\hline & PSA & 12 & 2 & 99\% Pseudomonas psychrophila & KJ626249 & 100 \\
\hline & & & & $99 \%$ Pseudomonas gessardii & KJ626251 & 90 \\
\hline & VRBGA & 10 & 0 & - & - & - \\
\hline & MRSA & 11 & 0 & - & - & - \\
\hline & Total & 189 & 38 & & & \\
\hline
\end{tabular}

a Temperature, the strains were isolated from naturally contaminated shrimps and assessed for spoilage potential at the same storage temperature.

b Pseudomonas selective agar.

c Violet red bile glucose agar.

d de Man, Rogosa and Sharp agar.

e The sequence identity is based on either forward or reverse primer.

reported by Chinivasagam et al. (1996), Heinsz et al. (1988), Mendes et al. (2002) in cold-water shrimp, but close to $5.7 \mathrm{log}$ CFU/g reported by Shamshad et al. (1990) in tropical shrimp. This confirms that in general, tropical shrimps carry higher initial numbers of bacteria, $10^{5}-10^{6} \mathrm{CFU} / \mathrm{g}$, than cold-water species, $10^{2}-10^{4} \mathrm{CFU} / \mathrm{g}$ (ICMSF, 2005).

Hydrogen sulfide-producing bacteria, which were found in this study to be the dominant group of microorganisms during storage at $7{ }^{\circ} \mathrm{C}$ and $28^{\circ} \mathrm{C}$, are well known as seafood spoilage bacteria. $\mathrm{H}_{2} \mathrm{~S}$ producing bacteria constitute the most relevant specific spoilage organisms in aerobically stored and vacuum packed marine fish (Skjerdal et al., 2004). One way to quantify $\mathrm{H}_{2} \mathrm{~S}$-producing bacteria in seafood is the use of iron agar supplemented with cysteine (Gram et al., 1987). Bacteria able to produce hydrogen sulfide $\left(\mathrm{H}_{2} \mathrm{~S}\right)$ when decomposing thiosulfate or cysteine present in IA medium, form black colonies due to precipitation of iron sulfide (FeS) (Gram et al., 1987). According to Skjerdal et al. (2004), this way of detecting $\mathrm{H}_{2} \mathrm{~S}$-producing bacteria has an advantage of reducing the risk of detecting false positives and negatives since the detection reaction is directly related to the spoilage property of $\mathrm{H}_{2} \mathrm{~S}$-producing bacteria. It has been reported that $\mathrm{H}_{2} \mathrm{~S}$-producing bacteria in seafood products are composed mainly of Shewanella baltica (Vogel et al., 2005; Serio et al., 2014), Shewanella morhuae (Serio et al., 2014), and S. putrefaciens (Chinivasagam et al., 1996; Gram et al., 1987; Koutsoumanis and Nychas, 1999; Mohan et al., 2010). The latter has been identified as the specific spoilage organism of iced marine fish (Gram and Dalgaard, 2002). However, in the present work, black colonies capable of producing strong off-odor isolated from iron agar and purified on TSA were identified by 16S rRNA sequencing as LAB. Our finding suggests that LAB are an important member of $\mathrm{H}_{2} \mathrm{~S}$-producing spoilage bacteria associated with tropical warm-water shrimp storage. The ability of some LAB to produce $\mathrm{H}_{2} \mathrm{~S}$ in food has been documented. For example, Lactobacillus sake spoils vacuum-packaged beef (Egan et al., 1989) and cold-smoked salmon (Joffraud et al., 2001) by producing $\mathrm{H}_{2} \mathrm{~S}$. Vagococcus species have been isolated from the microbiota of spoiled tropical 
cooked shrimp (Penaeus vannamei) (Jaffre et al., 2009). The authors of this work pointed out that it was the first time that the genus Vagococcus was isolated from a spoilage microbiota. However, they did not assess the spoilage potential of the isolates. In fact, not all members of spoilage microbiota of a product necessarily contribute to the spoilage of that product (Gram and Dalgaard, 2002). The present work showed that Vagococcus fluvialis is not only a member of spoilage microbiota of tropical shrimp but also a potential spoilage organism since it can produce $\mathrm{H}_{2} \mathrm{~S}$ and strong off-odor. Lactococcus garvieae was also isolated from spoilage microbiota of warm-water cooked and brined shrimp (Dalgaard et al., 2003).

Other spoilage LAB isolated from the same iron agar medium but as white colonies were Enterococcus faecalis $\left(7^{\circ} \mathrm{C}\right.$ and $\left.0{ }^{\circ} \mathrm{C}\right)$ and Carnobacterium maltaromaticum. Carnobacterium species have been reported to be the dominant part of spoilage association of cooked and brined modified atmosphere packed shrimps stored at $0{ }^{\circ} \mathrm{C}$ (Dalgaard et al., 2003). Mace et al. (2014) found that C. maltaromaticum is responsible for strong and rapid spoilage of cooked whole tropical shrimp stored under modified atmosphere packaging. E. faecalis has been isolated from the spoilage microbiota of shrimp stored at or above $15{ }^{\circ} \mathrm{C}$ (Dalgaard et al., 2003; Jaffres et al., 2009) and in the present study, the isolated E. faecalis was able to produce strong off-odor at $7{ }^{\circ} \mathrm{C}$ and $0^{\circ} \mathrm{C}$.

Apart from one isolate identified as Weissella cibaria, all the spoilage LAB in the present work were not isolated from MRSA but from IA. This could be justified by the fact that some LAB, mainly Carnobacterium species, grow poorly in MRSA due to the acetate contained in this medium (Leroi, 2010). In addition, the pH of MRSA (6.2) which is lower than the $\mathrm{pH}$ of IA (7.4) could be another reason. In fact, Peirson et al. (2003) found that LAB that cause green discoloration in cooked cured meat grew well in mildly alkaline broth but failed to grow at $\mathrm{pH}$ 5.4. They concluded that greening in cooked cured meat may be due to alkalitrophic $L A B$ and not to acidophilic LAB. Finally, the presence of cysteine in IA may have stimulated the growth of spoilage LAB since it is known that some LAB require cysteine for growth (Seefeldt and Weimer, 2000).

Our results on microbiological changes in shrimp during storage at $0{ }^{\circ} \mathrm{C}$ are in agreement with earlier observations that Pseudomonas spp. are the dominant microorganisms in tropical shrimps stored in ice (Chinivasagam et al., 1996, 1998; Jeyasekaran et al., 2006). According to Yumoto et al. (2001), Pseudomonas psychrophila was previously known as Pseudomonas sp. strain E-3. These authors found that strain E-3 was closest to P. fragi based on $16 \mathrm{~S}$ rRNA sequencing but low level of homology was found between them based on DNA-DNA hybridization. Therefore, they concluded that strain E-3 was an individual species and proposed the name $P$. psychrophila.

High storage temperature $\left(28^{\circ} \mathrm{C}\right)$ was considered in this study to reflect the situation of ambient temperature storage of shrimp, which sometimes occurs in Benin. Our results showed that high storage temperatures $\left(7{ }^{\circ} \mathrm{C}\right.$ and mainly $28{ }^{\circ} \mathrm{C}$ ) allow Enterobacteriaceae to produce strong off-odor when inoculated as pure culture in sterile shrimp. Enterobacteriaceae are known to produce indole and putrescine, which are considered as indicators of decomposition in shrimp (Bener et al., 2004; Mendes et al., 2002, 2005; Wunderlichova et al., 2013).

The initial value of TVBN (30.1 mg/100 g) found in the present work in $P$. notialis is similar to those reported earlier in other crustaceans. Zeng et al. (2005) reported an initial value of $33.5 \mathrm{mg} /$ $100 \mathrm{~g}$ in shrimp (Pandalus borealis). Lopez et al. (2007) found an initial value of $30 \mathrm{mg} / 100 \mathrm{~g}$ in pink shrimp (Parapenaeus longirostris). An initial value of $34 \mathrm{mg} / 100 \mathrm{~g}$ has been reported by Chinivasagam et al. (1996) in P. merguiensis. However, lower initial values of TVBN in shrimps have also been documented. Mendes et al. (2002) found an initial value of $26 \mathrm{mg} / 100 \mathrm{~g}$ in $P$. longirostris. Chinivasagam et al. (1996) found an initial value of $22 \mathrm{mg} / 100 \mathrm{~g}$ in Penaeus plebejus. A value as low as $2 \mathrm{mg} / 100 \mathrm{~g}$ has been reported in Chinese shrimp (Fenneropenaeus chinensis) (Lu, 2009). TVBN values depend on fish species and are related to the fish non-protein nitrogen content, which in turn depends on type of fish feeding; catching season and region; fish size, age, and sex as well as microbial activity (Goulas and Kontominas, 2007; Kilinc and Cakli, 2005). TVBN values may also depend on the methods used for their determination (Botta et al., 1984). Therefore, standard rejection values cannot be applied to all species of shrimp (Chinivasagam et al., 1996). Mendes et al. (2002) suggested a limit value of $60 \mathrm{mg} / 100 \mathrm{~g}$ for pink shrimp (P. longirostris). In the present work, values of shrimp at the sensory rejection times (88-104 mg/ $100 \mathrm{~g}$ ) suggest that a TVBN limit for $P$. notialis caught in tropical brackish waters may even be higher than $60 \mathrm{mg} / 100 \mathrm{~g}$.

In the present work, TVBN seems to be a good indicator of shrimp spoilage. A good correlation was observed between TVBN values and sensory scores even during storage at $0{ }^{\circ} \mathrm{C}$ where TVC counts were lower at sensory rejection time compared to TVC counts at $28{ }^{\circ} \mathrm{C}$ and $7{ }^{\circ} \mathrm{C}$. Evaluating the effect of temperature on bacterial load and microbiota composition in Norway lobster tail meat during storage, Gornik et al. (2011) also found that at sensory rejection time, the TVC counts were lower at $0{ }^{\circ} \mathrm{C}$ than the TVC counts at other storage temperatures $\left(4-16{ }^{\circ} \mathrm{C}\right)$. The authors hypothesized that although in low number, the microorganisms had more time (sensory rejection time at $0{ }^{\circ} \mathrm{C}$ longer than sensory rejection times at other storage temperatures) to produce metabolites that were accumulated over the storage period. The increase in TVBN levels at $0{ }^{\circ} \mathrm{C}$ while the TVC counts were relatively low could also be explained by the fact that in addition to microbial spoilage, shrimp tissue enzymes also contribute to the production of volatile bases (Matches, 1982; Mendes et al., 2002; LopezCaballaro et al., 2007).

The initial value of TMA in the present study was approximately twelve times lower than the initial TVBN value. A low level of TMA in comparison with TVBN is in agreement with earlier observations. It has been reported that the main component of TVBN in crustaceans is ammonia (Vanderzant et al., 1973; Yeh et al., 1978). The acceptability limit of TMA in shrimp is $5 \mathrm{mg} / 100 \mathrm{~g}$ according to Cobb et al. (1973). However, as for TVBN, this limit should not be applied for all species of shrimp. In this study, the TMA values at sensory rejections times ranged between 9 and $12 \mathrm{mg} / 100 \mathrm{~g}$. These values are similar to the value of $11.4 \mathrm{mg} / 100 \mathrm{~g}$ as the limit value of TMA for acceptable pink shrimp (Mendes et al., 2005).

The initial value of $\mathrm{pH}(7.4)$ is comparable to the initial values reported in other shrimp species by Zeng et al. (2005) (7.41), LopezCaballero et al. (2007) (7.3), Mendes et al. (2002) (7.1) and Goswami et al. (2001) (7.2). Like TVBN, pH increase during shrimp storage is due to enzymatic actions both endogenous and microbial which result in basic compounds production (Lopez-Caballaro et al., 2007). Our findings are in agreement with the report of Goswami et al. (2001), that the pH of shrimp is a fairly good indicator of its quality.

To assess the spoilage potential of microorganisms i.e. their ability to produce sensory defects, various sterile seafood substrates have been documented including sterile muscle blocks from a freshly killed seafood, ionized seafood, and heat-sterilized $\left(100{ }^{\circ} \mathrm{C}, 30 \mathrm{~min}\right)$ seafood juice (Gram and Huss, 1996; Joffraud et al., 1998; Leroi et al., 1998; Koutsoumanis and Nychas, 1999; Mace et al., 2014). Each of these treatments may fail to reproduce exactly the untreated product due to modification of the physicochemical composition of the product and inactivation of competitive flora (Gram and Huss, 1996; Leroi et al., 1998; Moini et al., 2009). Although heat-sterilization of seafood juice results in loss of amino acids (Leroi et al., 1998), heat-sterilization of whole 
shrimps seems to have less impact on the composition. Delfieh et al (2013) did not find any significant difference in protein and ash contents of raw and boiled $\left(100^{\circ} \mathrm{C}, 6 \mathrm{~min}\right)$ shrimp. In a comparative study of the spoilage of raw and boiled shrimps stored in $2{ }^{\circ} \mathrm{C}$, Mendes et al. (2002) showed that although the cooking step reduced the concentration of spoilage bacteria to below the detection limit in the beginning of storage, the microbiological and sensory spoilage were similar in both types of shrimps toward the end of storage (10-16 days).

The three temperatures used to develop the preliminary shelflife model cover temperature variation range in the supply chain (from $0{ }^{\circ} \mathrm{C}$ (ice) to ambient temperature $\left(28^{\circ} \mathrm{C}\right)$ ). Moreover, it has been demonstrated that three temperatures can be used to develop a shelf-life model prediction (Hough et al., 2006). The apparent activation energy estimated in this study $\left(80.2 \pm 4.5 \mathrm{~kJ} \mathrm{~mol}^{-1}\right)$ is in concordance with previous values found with fresh food from tropical water (Dalgaard and Huss, 1997). As mentioned earlier by Dalgaard and Jorgensen (2000), mathematical models used to predict the shelf-life of seafood products may generate important differences depending on the types of seafood products. The common model (6) (based on Ratkowsky model) for fresh seafood shelf-life prediction Shelf life $(T)=$ Shelf life $\left(T_{0}\right) /(1+0.1 \times T)^{2}(6)$ (with T, temperature $\left({ }^{\circ} \mathrm{C}\right)$ ) (Dalgaard and Huss, 1997) predicts a shelf-life of $16.5 \mathrm{~h}$ for a shelf-life of $11 \mathrm{~d}$ at $0{ }^{\circ} \mathrm{C}$ (the average found in our study) and a storage temperature of $30^{\circ} \mathrm{C}$. This prediction is unrealistic. The equation (6) fails to accurately predict the shelf-life when temperature abuse occurs because dominant spoilage flora shift from low temperature to high temperature (Dalgaard and Huss, 1997; Dalgaard and Jorgensen, 2000). An exponential model (7) for tropical fresh seafood shelf-life prediction has been proposed by Dalgaard and Huss (1997). Shelf life $(\mathrm{T})=$ Shelf life $\left(\mathrm{T}_{0}\right) \times \exp (-0.12 \times T)(7)$ with $\mathrm{T}$, temperature $\left({ }^{\circ} \mathrm{C}\right)$. This model gives predictions similar to the developed model in this study, especially at high storage temperature. For example, at $30^{\circ} \mathrm{C}$, the generated model in this study (equation (5)) predicts a shelf-life of $7.2 \mathrm{~h}$. At the same temperature $\left(30^{\circ} \mathrm{C}\right)$ and for a shelf-life of $11 \mathrm{~d}$ at $0{ }^{\circ} \mathrm{C}$, the model by Dalgaard and Huss (1997) (equation (7)) gives exactly the same prediction of $7.2 \mathrm{~h}$. However, at $3{ }^{\circ} \mathrm{C}$, the model generated in this study predicts a shelf-life of 6.8 days, while the model by Dalgaard and Huss (1997) predicts a shelflife of almost one day longer (7.7 days).

In conclusion, the present work shows that the spoilage associations of shrimp (P. notialis) caught from brackish waters in Benin are storage temperature-dependent. During storage in ice $\left(0{ }^{\circ} \mathrm{C}\right)$, Pseudomonas spp. were dominant, whereas at $7{ }^{\circ} \mathrm{C}$ and $28^{\circ} \mathrm{C}_{2} \mathrm{~S}$ producing bacteria were the dominant group of microorganisms. The potential spoilage organisms identified at $0{ }^{\circ} \mathrm{C}$ were Pseudomonas spp. and LAB. At $7{ }^{\circ} \mathrm{C}$ and $28{ }^{\circ} \mathrm{C}$, LAB and Enterobacteriaceae were the main potential spoilage organisms. Good correlations were found between the sensory scores and the chemical indicators measured especially with TVBN and TMA. Therefore, TVBN or TMA can be used as an indicator of $P$. notialis quality. Modeling the spoilage kinetics of the relevant spoilage organisms in future studies will facilitate advising the stakeholders on the points in the supply chain that require special care to improve shrimp quality.

\section{Acknowledgements}

The authors would like to thank the Netherlands Universities Foundation For International Cooperation, project NPT/BEN/263 for financial support. The authors are also grateful to Dr. Françoise Leroi (Ifremer, France) and Prof. Joop Luten (Nofima, Norway) for their advice while designing the present study.

\section{Appendix A. Supplementary data}

Supplementary data related to this article can be found at http:// dx.doi.org/10.1016/j.fm.2014.11.005.

\section{References}

Altschul, S.F., Gish, W., Miller, W., Myers, E.W., Lipman, D.J., 1990. Basic local alignment search tool. J. Mol. Biol. 215, 403-410.

Argyri, A.A. Panagou, E.Z. Tarantilis, P.A., Polysiou, M. Nychas, G.J. 2010. Rapid qualitative and quantitative detection of beef fillets spoilage based on Fourier transform infrared spectroscopy data and artificial neural networks. Sensors Actuators B Chem. 145, 146-154.

Benner, R.A., Staruszkiewicz, W.F., Otwell, W.S., 2004. Putrescine, cadaverine, and indole production by bacteria isolated from wild and aquacultured penaeid shrimp stored at $0,12,24$, and $36^{\circ} \mathrm{C}$. J. Food Prot. 67, 124-133.

Botta, J.R., Lauder, J.T. Jewer, M.A., 1984. Effect of methodology on total volatile basic nitrogen (TVB-N) determination as an index of quality of fresh Atlantic cod (Gadus morhua). J. Food Sci. 49, 734-736.

Broekaert, K., Heyndrickx, M., Herman, L., Devlieghere, F., Vlaemynck, G., 2011. Seafood quality analysis: molecular identification of dominant microbiota after ice storage on several general growth media. Food Microbiol. 28, 1162-1169.

Chan, S.T., Yao, M.W.Y., Wong, Y.C., Wong, T., Mok, C.S., Sin, D.W.M., 2006. Evaluation of chemical indicators for monitoring freshness of food and determination of volatile amines in fish by headspace solid-phase microextraction and gas chromatography-mass spectrometry. Eur. Food Res. Technol. 224, 67-74.

Chen, J., Deng, S., Li, J., 2013. Preparation of a novel botanic biopreservative and its efficacy in keeping quality of peeled Penaeus vannamei. Food Sci. Technol. Int. $19,251-260$.

Chinivasagam, H.N., Bremner, H.A., Wood, A.F., Nottingham, S.M., 1998. Volatile components associated with bacterial spoilage of tropical prawns. Int. J. Food Microbiol. 42, 45-55.

Chinivasagam, H.N., Bremner, H.A., Thrower, S.J., Nottingham, S.M., 1996. Spoilage pattern of five species of Australian prawns: deterioration is influenced by environment of capture and mode of storage. J. Aquatic Food Prod. Technol. 5 25-50.

Cobb, B.F., Vanderzant, C., Thompson, C.A., Custer, C.S., 1973. Chemical characteristics, bacterial counts and potential shelf-life of shrimp from various locations on the northwestern Gulf of Mexico. J. Milk Food Technol. 36, 463-468.

Dabadé, D.S., den Besten, H.M.W., Azokpota, P., Nout, M.J.R., Hounhouigan, D.J., Zwietering, M.H., 2014. Quality perceptions of stakeholders in Beninese exportoriented shrimp chain. J. Food Prot. 77, 1642-1648.

Dalgaard, P., Vancanneyt, M., Euras Vilalta, N., Swings, J., Fruekilde, P., Leisner, J.J., 2003. Identification of lactic acid bacteria from spoilage associations of cooked and brined shrimps stored under modified atmosphere between $0{ }^{\circ} \mathrm{C}$ and $25^{\circ} \mathrm{C}$. J. Appl. Microbiol. 94, 80-89.

Dalgaard, P., Jorgensen, L.V., 2000. Cooked and brined shrimps packed in a modified atmosphere have a shelf-life of $>7$ months at $0{ }^{\circ} \mathrm{C}$, but spoil in $4-6$ days at $25^{\circ} \mathrm{C}$. Int. J. Food Sci. Technol. 35, 431-442.

Dalgaard, P., Huss, H.H., 1997. Mathematical modeling used for evaluation and prediction of microbial fish spoilage. In: Shahidi, F., Jones, Y., Kitts, D.D. (Eds.), Seafood Safety, Processing and Biotechnology. Technomic pub. Co. Inc, Lancaster, PA, pp. 73-89.

Dalgaard, P., Gram, L., Huss, H.H., 1993. Spoilage and shelf-life of cod fillets packed in vacuum or modified atmospheres. Int. J. Food Microbiol. 19, 283-294.

Delfieh, P., Rezaei, M., Hosseini, H., Vali Hosseini, S., Zohrehbakhsh, E., Regenstein, J.M., 2013. Effects of cooking methods on proximate composition and fatty acids profile of Indian white prawn (Fenneropenaeus indicus). J. Aquatic Food Prod. Technol. 22, 353-360.

Den Besten, H.M.W., Mataragas, M., Moezelaar, R., Abee, T., Zwietering, M.H., 2006. Quantification of the effects of salt stress and physiological state on thermotolerance of Bacillus cereus ATCC 10987 and ATCC 14579. Appl. Environ. Microbiol. 72, 5884-5894.

Egan, A.F., Shay, B.J., Rogers, P.J., 1989. Factors affecting the production of hydrogen sulphide by Lactobacillus sake L13 growing on vacuum-packaged beef. J. Appl. Bacteriol. 67, 255-262.

European Commission, 2005. Commission Regulation No 2074/2005, annex II, section II, chapter III. Determination of the concentration of TVBN in fish and fishery products. Off. J. Eur. Union L338, 27-59.

Giuffrida, A., Valenti, D., Giarratana, F., Ziino, G., Panebianco, A., 2013. A new approach to modelling the shelf life of Gilthead seabream (Sparus aurata). Int. J. Food Sci. Technol. 48, 1235-1242.

Gornik, S.G., Albalat, A., Macpherson, H., Birkbeck, H., Neil, D.M., 2011. The effect of temperature on the bacterial load and microbial composition in Norway lobster (Nephrops norvegicus) tail meat during storage. J. Appl. Microbiol. 111, 582-592.

Goswami, T.K., Ravindra, M.R., Nayak, T.K., 2001. Time-temperature relationships for IQF shrimp with liquid nitrogen and its quality assessment. J. Food Process Eng. $24,71-85$.

Goulas, A.E., Kontominas, M.G., 2007. Combined effect of light salting, modified atmosphere packaging and oregano essential oil on the shelf-life of sea bream (Sparus aurata): biochemical and sensory attributes. Food Chem. 100, 287-296.

Gram, L., Dalgaard, P., 2002. Fish spoilage bacteria - problems and solutions. Curr. Opin. Biotechnol. 13, 262-266. 
Gram, L., Huss, H.H., 1996. Microbiological spoilage of fish and fish products. Int. J. Food Microbiol. 31, 121-137.

Gram, L., Trolle, G., Huss, H.H., 1987. Detection of specific spoilage bacteria from fish stored at low $\left(0^{\circ} \mathrm{C}\right)$ and high $\left(20^{\circ} \mathrm{C}\right)$ temperatures. Int. J. Food Microbiol. 4 , 65-72.

Heinsz, L.J., Harrison, M.A., Leiting, V.A., 1988. Microflora of brown shrimp (Penaeus aztecus) from Georgia coastal waters. Food Microbiol. 5, 141-145.

Hough, G., Garitta, L., Gómez, G., 2006. Sensory shelf-life predictions by survival analysis accelerated storage models. Food Qual. Prefer. 17, 468-473.

Hubert, T., Faulkner, G., Hugenholtz, P., 2004. Bellerophon; a program to detect chimeric sequences in multiple sequence alignments. Bioinformatics 20, 2317-2319.

ICMSF, 2005. Microbiology in Foods 6: Microbial Ecology of Food Commodities, second ed. Kluwer Academic/Plenum Publishers, New York (Chapter 3).

Jaffres, E., Sohier, D., Leroi, F., Pilet, M.F., Prevost, H., Joffraud, J.-J., Dousset, X., 2009. Study of the bacterial ecosystem in tropical cooked and peeled shrimps using a polyphasic approach. Int. J. Food Microbiol. 131, 20-29.

Jeyasekaran, G., Ganesan, P., Anandaraj, R., Shakila, R.J., Sukumar, D., 2006. Quantitative and qualitative studies on the bacteriological quality of Indian white shrimp (Penaeus indicus) stored in dry ice. Food Microbiol. 23, 526-533.

Joffraud, J.J., Leroi, F., Chevalier, F., 1998. Development of a sterile cold-smoked fish model. J. Appl. Microbiol. 85, 991-998.

Joffraud, J.J., Leroi, F., Roy, C., Berdague, J.L., 2001. Characterization of volatile compounds produced by bacteria isolated from the spoilage flora of coldsmoked salmon. Int. J. Food Microbiol. 66, 175-184.

Kilinc, B., Cakli, S., 2005. Determination of the shelf life of sardine (Sardina pilchardus) marinades in tomato sauce stored at $4{ }^{\circ} \mathrm{C}$. Food Control 16, 639-644.

Koutsoumanis, K., Nychas, G.J.E., 1999. Chemical and sensory changes associated with microbial flora of Mediterranean boque (Boops boops) stored aerobically at 0, 3, 7 and $10^{\circ} \mathrm{C}$. Appl. Environ. Microbiol. 65, 698-706.

Leroi, F., Joffraud, J.J., Chevalier, F., Cardinal, M., 1998. Study of the microbial ecology of cold-smoked salmon during storage at $8{ }^{\circ} \mathrm{C}$. Int. J. Food Microbiol. 39, $111-121$.

Leroi, F., 2010. Occurrence and role of lactic acid bacteria in seafood products. Food Microbiol. 27, 698-709.

Lopez-Caballero, M.E., Martinez-Alvarez, O., Gomez-Guillen, M.C., Montero, P., 2007. Quality of thawed deepwater pink shrimp (Parapenaeus longirostris) treated with melanosis-inhibiting formulations during chilled storage. Int. J. Food Sci. Technol. 42, 1029-1038.

Lu, S., 2009. Effects of bactericides and modified atmosphere packaging on shelf-life of Chinese shrimp (Fenneropenaeus chinensis). LWT Food Sci. Technol. 42, 286-291.

Mace, S., Cardinal, M., Jaffre, E., Cornet, J., Lalanne, V., Chevalier, F., Serot, T., Pilet, M.F., Dousset, X., Joffraud, J.-J., 2014. Evaluation of the spoilage potential of bacteria isolated from spoiled cooked whole tropical shrimp (Penaeus vannamei) stored under modified atmosphere packaging. Food Microbiol. 40, 9-17.

Magnusson, H., Sveinsdottir, K., Lauzon, H., Thorkelsdottir, A., Martinsdottir, E., 2006. Keeping quality of desalted cod fillets in consumer packs. J. Food Sci. 71, M69-M76.

Mai, N.T., Gudjónsdóttir, M., Lauzon, H.L., Sveinsdóttir, K., Martinsdóttir, E., Audorff, H., Reichstein, W., Haarer, D., Bogason, S.G., Arason, S., 2011. Continuous quality and shelf life monitoring of retail-packed fresh cod loins in comparison with conventional methods. Food control 22, 1000-1007.

Malle, P., Tao, S.H., 1987. Rapid quantitative determination of trimethylamine using steam distillation. J. Food Prot. 50, 756-760.

Martínez-Alvarez, O., López-Caballero, M.E., Gómez-Guillén, M.C., Montero, P., 2009. The effect of several cooking treatments on subsequent chilled storage of thawed deepwater pink shrimp (Parapenaeus longirostris) treated with different melanosis-inhibiting formulas. LWT Food Sci. Technol. 42, 1335-1344.

Matches, J.R., 1982. Effects of temperature on the decomposition of Pacific coast shrimp (Pandalus jordani). J. Food Sci. 47, 1044-1047.

Mejlholm, O., Boknaes, N., Dalgaard, P., 2005. Shelf life and safety aspects of chilled cooked and peeled shrimps (Pandalus borealis) in modified atmosphere packaging. J. Appl. Microbiol. 99, 66-76.
Mejlholm, O., Kjeldgaard, J., Modberg, A., Vest, M.B., Bøknæs, N., Koort, J. Björkroth, J., Dalgaard, P., 2008. Microbial changes and growth of Listeria monocytogenes during chilled storage of brined shrimp (Pandalus borealis). Int. J. Food Microbiol. 124, 250-259.

Mendes, R., Goncalves, A., Pestana, J., Pestana, C., 2005. Indole production and deepwater pink shrimp (Parapenaeus longirostris) decomposition. Eur. Food Res. Technol. 221, 320-328.

Mendes, R., Huidobro, A., Lopez Caballero, E., 2002. Indole levels in deepwater pink shrimp (Parapenaeus longirostris) from the Portuguese coast. Effects of temperature abuse. Eur. Food Res. Technol. 214, 125-130.

Mohan, C.O., Ravishankar, C.N., Gopal, T.K.S., Lalitha, K.V., Kumar, K.A., 2010. Effect of reduced oxygen atmosphere and sodium acetate treatment on the microbia quality changes of seer fish (Scomberomorus commerson) steaks stored in ice. Food Microbiol. 27, 526-534.

Moini, S., Tahergorabi, R., Hosseini, S.V., Rabbani, M., Tahergorabi, Z., Feas, X., Aflaki, F., 2009. Effect of gamma radiation on the quality and shelf life of refrigerated rainbow trout (Oncorhynchus mykiss) fillets. J. Food Prot. 72, 1419-1426.

Pacquit, A., Frisby, J., Diamond, D., Lau, K.T., Farrell, A., Quilty, B., Diamond, D., 2007. Development of a smart packaging for the monitoring of fish spoilage. Food Chem. 102, 466-470.

Peirson, M.D., Guan, T.Y., Holley, R.A., 2003. Aerococci and carnobacteria cause discoloration in cooked cured bologna. Food Microbiol. 20, 149-158.

Ratkowsky, D.A., Olley, J., McMeekin, T.A., Ball, A., 1982. Relationship between temperature and growth rate of bacterial cultures. J. Bacteriol. 149, 1-5.

Rodríguez-Calleja, J.M., Cruz-Romero, M.C., O'Sullivan, M.G., García-López, M.L., Kerry, J.P., 2012. High-pressure-based hurdle strategy to extend the shelf-life of fresh chicken breast fillets. Food Control 25, 516-524.

Seefeldt, K.E., Weimer, B.C., 2000. Diversity of sulfur compound production in lactic acid bacteria. J. Dairy Sci. 83, 2740-2746.

Serio, A., Fusella, G.C., Chaves López, C., Sacchetti, G., Paparella, A., 2014. A survey on bacteria isolated as hydrogen sulfide-producers from marine fish. Food Control 39, 111-118.

Shamshad, S.I., Kher, U.N., Riaz, M., Zuberi, R., Qadri, R.B., 1990. Shelf life of shrimp (Penaeus merguiensis) stored at different temperatures. J. Food Sci. 55, 1201-1205.

Skjerdal, O.T., Lorentzen, G., Tryland, I., Berg, J.D., 2004. New method for rapid and sensitive quantification of sulphide-producing bacteria in fish from arctic and temperate waters. Int. J. Food Microbiol. 93, 325-333.

Vanderzant, C., Cobb, B.F., Thompson, C.J., Parker, J.C., 1973. Microbial flora, characteristics, and shelf life of four species of pond-reared shrimp. J. Milk Food Technol. 36, 443-446.

Vogel, B.F., Venkateswaran, K., Satomi, M., Gram, L., 2005. Identification of Shewanella baltica as the most important $\mathrm{H}_{2} \mathrm{~S}$-producing species during iced storage of Danish marine fish. Appl. Environ. Microbiol. 71, 6689-6697.

Wan Norhana, M.N., Poole, S.E., Deeth, H.C., Dykes, G.A., 2010. Prevalence, persistence and control of Salmonella and Listeria in shrimp and shrimp products: a review. Food Control 21, 343-361.

Wunderlichova, L., Bunkova, L., Koutny, M., Valenta, T., Bunka, F., 2013. Novel touchdown-PCR method for the detection of putrescine producing Gramnegative bacteria in food products. Food Microbiol. 34, 268-276.

Yeh, C.-P.S., Nickelson, R., Finne, G., 1978. Ammonia producing enzymes in white shrimp tails. J. Food Sci. 43, 1400-1401, 1404.

Yumoto, I., Kusano, T., Shingyo, T., Nodasaka, Y., Matsuyama, H., Okuyama, H., 2001. Assignment of Pseudomonas sp. strain E-3 to Pseudomonas psychrophila sp.nov., a new facultatively psychrophilic bacterium. Extremophiles 5, 343-349.

Zeng, Q.Z., Thorarinsdottir, K.A., Olafsdottir, G., 2005. Quality changes of shrimp (Pandalus borealis) stored under different cooling conditions. J. Food Sci. 70, S459-S466.

Zheng, X.W., Yan, Z., Han, B.Z., Zwietering, M.H., Samson, R.A., Boekhout, T., Nout, M.J.R., 2012. Complex microbiota of a Chinese "Fen" liquor fermentation starter (Fen-Daqu), revealed by culture-dependent and culture-independent methods. Food Microbiol. 31, 293-300. 